\title{
A Clinicopathological Study of Spectrum of Pigmented Skin Lesions in Southern India: A Three Year Experience at a Tertiary Care Centre with Review of Literature
}

\author{
${ }^{1}$ Post Graduate Resident, Department of Laboratory Medicine, Command Hospital Air Force, Bangalore, 560007, India \\ ${ }^{2}$ Associate Professor, Department of Laboratory Medicine, Command Hospital Air Force Bangalore, 560007, India \\ ${ }^{3}$ Assistant Professor, Department of Laboratory Medicine, Command Hospital Air Force Bangalore, 560007, India \\ ${ }^{4}$ Professor \& HOD, Department of Laboratory Medicine, Command Hospital Air Force Bangalore, 560007, India \\ ${ }^{5}$ Associate Professor, Department of Dermatology, Command Hospital Air Force, Bangalore, 560007, India \\ ${ }^{6}$ Post Graduate Resident, Department of Dermatology, Command Hospital Air Force, Bangalore, 560007, India
}

Dr. Abhishek Singh ${ }^{1}$, Dr. Pragya Sharma ${ }^{2 *}$, Dr. Akriti Kashyap ${ }^{3}$, Dr. Arijit Sen ${ }^{4}$, Dr. Rajeshwari Dabas ${ }^{5}$, Dr. Reetika Pal ${ }^{6}$

DOI: $\underline{10.36348 / \text { sjpm.2020.v05i10.005 }}$

| Received: 13.10 .2020 | Accepted: 26.10 .2020 | Published: 29.10 .2020

*Corresponding author: Dr. Pragya Sharma

\section{Abstract}

Pigmented skin lesions refer to lesions that are black, brown or blue in color. These lesions include both melanocytic and non-melanocytic lesions. A number of pigmented lesions are difficult to classify because of wide spectrum of histological appearances and raise the possibility of melanoma. With this study we intended to evaluate the spectrum of pigmented skin lesions and to correlate the clinical diagnosis with the histological diagnosis. In this retrospective study, 75 cases of pigmented skin lesions were reviewed on hematoxylin and eosin stained paraffin embedded tissue sections from June 2017- May 2020 in the Department of Pathology at a Tertiary Care Hospital and analyzed according to age, gender, site of occurrence and histological types. Out of the 75cases evaluated there were 23 melanocytic lesions and 52 nonmelanocytic lesions. Overall, benign melanocytic nevi (13 cases) were commonest lesions followed by seborrheic keratosis $\left(11\right.$ cases). The lesions presented from $1^{\text {st }}-9^{\text {th }}$ decade with slight female predominance. The most common site involved was head and neck. Clinicohistopathological correlation showed positive correlation in 55(73.3\%) cases and negative correlation in 20 cases (26.6\%). Pigmented skin lesions are common presenting problem, while majority are benign a small minority can be malignant. A histological interpretation by pathologist is essential to correctly diagnose these lesions in order not to miss a small percentage of malignant tumors and to differentiate melanocytic lesions from its nonmelanocytic mimickers.

Keywords: Pigmented skin lesions, Benign melanocytic nevi, Malignant melanoma, Seborrheic keratosis, Basal cell carcinoma, Dermatofibrosarcoma protuberans.

Copyright (C) 2020 The Author(s): This is an open-access article distributed under the terms of the Creative Commons Attribution 4.0 International License (CC BY-NC 4.0) which permits unrestricted use, distribution, and reproduction in any medium for non-commercial use provided the original author and source are credited.

\section{INTRODUCTION}

Pigmented skin lesions (PSLs) refer to lesions that are black, brown or blue in color [1]. These lesions include both melanocytic and non-melanocytic lesions. A number of pigmented lesions are difficult to classify because of wide spectrum of histological appearances and raise the possibility of a melanoma [2]. Melanocytic lesions can develop from abnormal migration of melanocytes from neural crest to the skin during embryogenesis, impaired melanosome transfer to keratinocytes and alteration in melanin synthesis [3]. Melanocytic proliferations include the three related cell types: melanocytes, nevus cells or melanoma cells, each of which may be present in epidermis or dermis and infrequently in subcutis. Benign neoplasms of nevus cells are called melanocytic nevi, while malignant neoplasms are called malignant melanoma [4]. Nonmelanocytic lesions can be keratinocytic, vascular, or reactive [1]. Some of these include seborrheic keratosis, basal cell carcinoma, actinic keratosis, dermatofibrosarcoma protuberans, lichen planus pigmentosus, and vasoformative lesions. A careful histopathological evaluation is essential in making the correct diagnosis of the PSL. The study was conducted to understand the spectrum of pigmented skin lesions with reference to age, sex, site and histopathological diagnosis in Southern India.

\section{MATERIAL AND METHODS}

This was a retrospective study of the histologically diagnosed pigmented skin lesions over a 
span of three years from June 2017 to May 2020. Out of 1108 skin biopsies received over the three years, 75 clinically and histologically diagnosed PSLs were selected for the study. Data including demographic details, clinical diagnosis and clinical evidence of pigmentation were retrieved from histopathology requisition forms and patient case sheets. The hematoxylin \& eosin stained slides of skin biopsies were reviewed and analyzed according to age, gender, site of occurrence and histological types.

\section{RESULTS}

In the present study, out of 1108 skin biopsies received, 6\% (75) were diagnosed as PSLs. These 75 PSLs were further categorized, into melanocytic 23 $(30.6 \%)$ and non-melanocytic $52(69.4 \%)$ pigmented lesions (Table-1).

Table-1: Distribution of pigmented Melanocytic and Non melanocytic lesions

\begin{tabular}{|l|l|l|}
\hline Lesions & & No of cases (n=75) (\%) \\
\hline \multirow{4}{*}{ Melanocytic Lesions } & Benign melanocytic nevi & $13(17.3)$ \\
\cline { 2 - 3 } & Malignant Melanoma & $10(13.3)$ \\
\hline & Dermatofibrosarcoma protuberans & $2(2.7)$ \\
\cline { 2 - 3 } & Keratoacanthoma & $1(1.3)$ \\
\cline { 2 - 3 } & Post Inflammatory hyperpigmentation & $5(6.7)$ \\
\cline { 2 - 3 } & Dermatofibroma & $10(13.3)$ \\
\cline { 2 - 3 } & Seborrheic keratosis & $11(14.7)$ \\
\cline { 2 - 3 } & Basal cell carcinoma & $7(9.4)$ \\
\cline { 2 - 3 } & Lichen planus pigmentosus & $8(10.7)$ \\
\cline { 2 - 3 } & Lobular Capillary Hemangioma & $4(5.3)$ \\
\cline { 2 - 3 } & Cavernous Hemangioma & $3(4)$ \\
\cline { 2 - 3 } & Angiokeratoma & $1(1.3)$ \\
\hline Total & & $75(100)$ \\
\hline
\end{tabular}

Out of these, $31(41.3 \%)$ cases were males, 44 cases $(58.7 \%)$ were females, with male: female ratio of 1:1.4 (Table-2)

Table-2: Showing distribution of lesions among males $(n=31)$ and females $(n=44)$

\begin{tabular}{|l|l|l|l|}
\hline Lesions & & Males (\%) & Females (\%) \\
\hline Melanocytic Lesions & Benign Melanocytic nevi & $6(8)$ & $7(9.3)$ \\
\cline { 2 - 4 } & Malignant Melanoma & $4(5.3)$ & $6(8)$ \\
\hline \multirow{5}{*}{ Non Melanocytic Lesions } & Dermatofibrosarcoma protuberans & - & $2(2.7)$ \\
\cline { 2 - 4 } & Keratoacanthoma & $1(1.3)$ & - \\
\cline { 2 - 4 } & Post- Inflammatory hyperpigmentation & $4(5.3)$ & $1(1.3)$ \\
\cline { 2 - 4 } & Dermatofibroma & $4(5.3)$ & $6(8)$ \\
\cline { 2 - 4 } & Seborrheic keratosis & $3(4)$ & $8(10.7)$ \\
\cline { 2 - 4 } & Basal cell carcinoma & $3(4)$ & $4(5.3)$ \\
\cline { 2 - 4 } & Lichen planus pigmentosus & $4(5.3)$ & $4(5.3)$ \\
\cline { 2 - 4 } & Lobular capillary hemangioma & $2(2.7)$ & $2(2.7)$ \\
\cline { 2 - 4 } & Cavernous hemangioma & - & $3(4)$ \\
\cline { 2 - 3 } & Angiokeratoma & - & $1(1.3)$ \\
\hline \multirow{5}{*}{ Total } & $31(41.3)$ & $44(58.7)$ \\
\hline
\end{tabular}

The age of the patients ranged from 4 months old -84 years Maximum cases presented in $3^{\text {rd }}$ decade of life $(21.3 \%)$. The commonest lesions in the third decade being, benign melanocytic nevi followed by lichen planus pigmentosus (Table-3).

Also, benign melanocytic nevi were the most common among both sexes $(17.3 \%)$ followed by seborrheic keratosis (14.7\%) (Table-2). Of the 13 benign nevi, there were $9(69.2 \%)$ cases of intradermal nevi, $3(23.1 \%)$ cases of compound nevi and $1(7.7 \%)$ case of congenital melanocytic nevus. There were $10(13.3 \%)$ cases of malignant melanoma with slight female predilections (Table-2) with increased occurrence in $5^{\text {th }}, 6^{\text {th }}$ and $8^{\text {th }}$ decades (Table-3). Among the 53 non melanocytic pigmented lesions, seborrheic keratosis was most common $11(20.7 \%)$ followed by dermatofibroma 10(18.8\%). Both showed increased incidence in females (Table-2). 
Table-3: Distribution of pigmented lesions among different age groups

\begin{tabular}{|l|l|l|l|l|l|l|l|}
\hline Lesions & $\mathbf{2 1 y r}$ & $\mathbf{2 1 - 3 0 y r}$ & $\mathbf{3 1 - 4 0 y r}$ & $\mathbf{4 1 - 5 0 y r}$ & $\mathbf{5 1 - 6 0 y r}$ & $\mathbf{6 1 - 7 0 y r}$ & $>\mathbf{7 0 y r}$ \\
\hline Benign melanocytic nevi (n=13) (\%) & $2(15.3)$ & $7(53.8)$ & $1(7.7)$ & $1(7.7)$ & $1(7.7)$ & $1(7.7)$ & - \\
\hline Malignant melanoma (n=10) (\%) & - & - & - & $1(10)$ & $5(50)$ & - & $4(40)$ \\
\hline $\begin{array}{l}\text { Dermatofibrosarcoma } \\
\text { protuberans (n=2) (\%) }\end{array}$ & $1(50)$ & - & $1(50)$ & - & - & - & - \\
\hline Keratoacanthoma (n=1) (\%) & - & - & - & - & $1(100)$ & - & - \\
\hline $\begin{array}{l}\text { Post inflammatory } \\
\text { hyperpigmentation (n=6) (\%) }\end{array}$ & $1(20)$ & $1(20)$ & $1(20)$ & $1(20)$ & $1(20)$ & $1(20)$ & \\
\hline Dermatofibroma (n=10) (\%) & $1(10)$ & $2(20)$ & $4(40)$ & $2(20)$ & - & $1(10)$ & \\
\hline Seborrheic keratosis (n=11) (\%) & - & $1(9.1)$ & - & $3(27.3)$ & $4(36.4)$ & $2(18.2)$ & $1(9.1)$ \\
\hline Basal cell carcinoma (n=7) (\%) & - & - & - & $1(14.3)$ & $1(14.3)$ & - & $5(71.4)$ \\
\hline Lichen planus pigmentosus (n=8) (\%) & $1(12.5)$ & $3(37.5)$ & $2(25)$ & $2(25)$ & - & - & - \\
\hline Lobular capillary hemangioma (n=4) (\%) & - & $2(50)$ & $1(25)$ & - & - & $1(25)$ & - \\
\hline Cavernous hemangioma (n=3) (\%) & - & $1(33.33)$ & $1(33.33)$ & $1(33.33)$ & - & - & - \\
\hline Angiokeratoma(n=1) (\%) & - & - & - & - & - & $1(100)$ & - \\
\hline
\end{tabular}

Most commonly involved site was the head and neck region including the face, 29(38.6\%) (Table $4 \mathrm{a} \& 4 \mathrm{~b}$ ). While the benign melanocytic lesions were distributed predominantly over head, face, abdomen and back, lesions of malignant melanoma showed variable distribution (Table-4a).

Table-4a: Distribution of melanocytic lesions on various sites

\begin{tabular}{|l|l|l|}
\hline Site & Benign Melanocytic nevi $(\mathbf{n = 1 3})(\boldsymbol{\%})$ & Malignant Melanoma $(\mathbf{n}=\mathbf{1 0})(\%)$ \\
\hline Eyebrow & $1(7.7)$ & - \\
\hline Eyelid & $2(15.3)$ & - \\
\hline Forehead & $1(7.7)$ & - \\
\hline Ala of nose & $2(15.3)$ & - \\
\hline Cheek & $1(7.7)$ & - \\
\hline Chin & $1(7.7)$ & - \\
\hline Temporal area & $1(7.7)$ & - \\
\hline Scalp & $1(7.7)$ & - \\
\hline Neck & - & $1(10)$ \\
\hline Back & $1(7.7)$ & $1(10)$ \\
\hline Abdomen & $1(7.7)$ & $2(20)$ \\
\hline Shoulder & $1(7.7)$ & $3(30)$ \\
\hline Labia & - & $1(10)$ \\
\hline Sole & - & $2(20)$ \\
\hline Total & 13 & 10 \\
\hline
\end{tabular}

Table-4b: Distribution of non melanocytic lesions on various sites

\begin{tabular}{|c|c|c|c|c|c|c|c|c|c|c|}
\hline Site & $\begin{array}{r}\operatorname{DFSP}(\mathrm{n}=2) \\
(\%)\end{array}$ & $\begin{array}{r}\mathbf{K A}(\mathbf{n}=1) \\
(\%)\end{array}$ & $\begin{array}{r}\text { PIH } \\
(\mathbf{n}=5) \\
(\%)\end{array}$ & $\begin{array}{r}\mathrm{DF}(\mathrm{n}=10) \\
(\%)\end{array}$ & $\begin{array}{r}\text { SK }(\mathrm{n}=11) \\
(\%)\end{array}$ & $\begin{array}{r}\mathrm{BCC}(\mathrm{n}=7) \\
(\%)\end{array}$ & $\begin{array}{r}\operatorname{LPP}(\mathbf{n}=8) \\
(\%)\end{array}$ & $\begin{array}{r}\mathbf{L C H} \\
(\mathrm{n}=4) \\
(\%)\end{array}$ & $\begin{array}{r}\mathrm{CH}(\mathrm{n}=3) \\
(\%)\end{array}$ & $\begin{array}{r}\text { AK } \\
(\mathbf{n}=1) \\
(\%)\end{array}$ \\
\hline Forehead & - & - & - & - & - & $1(14.3)$ & - & - & - & - \\
\hline Ala of nose & - & - & - & - & $1(9.1)$ & $1(14.3)$ & - & - & - & - \\
\hline Cheek & - & - & - & - & - & - & - & & - & - \\
\hline Temporal area & - & - & - & $1(10)$ & $1(9.1)$ & $3(42.8)$ & - & - & - & - \\
\hline Scalp & $1(50)$ & - & - & - & $218.2)$ & - & - & $1(25)$ & - & - \\
\hline Ear & - & - & - & - & $2(18.2)$ & - & - & - & - & - \\
\hline Neck & $1(50)$ & - & $2(40)$ & - & - & - & - & - & - & - \\
\hline Chest & - & - & - & - & - & - & - & - & 1(33.3) & - \\
\hline Back & - & - & - & - & $1(9.1)$ & - & $2(25)$ & - & - & - \\
\hline Abdomen & - & - & $1(20)$ & - & $2(18.1)$ & - & - & - & - & - \\
\hline Forearm & - & - & - & $5(50)$ & - & - & $1(12.5)$ & - & - & - \\
\hline Hand & - & - & - & - & - & - & $2(25)$ & $1(25)$ & - & - \\
\hline Shoulder & - & - & - & - & - & - & $1(12.5)$ & - & - & - \\
\hline Penis & - & - & - & - & - & - & $1(12.5)$ & - & - & - \\
\hline Thigh & - & - & $1(20)$ & $1(10)$ & $1(9.1)$ & $2(28.6)$ & - & - & - & - \\
\hline Knee & - & - & - & - & $1(9.1)$ & - & - & - & - & - \\
\hline Gluteal & & - & $1(20)$ & 1(10) & - & - & - & - & - & - \\
\hline Leg & - & - & - & $1(10)$ & - & - & $1(12.5)$ & - & $2(66.7)$ & - \\
\hline Scrotum & - & $1(100)$ & - & - & - & - & - & - & - & $1(100)$ \\
\hline Foot & - & - & - & $1(10)$ & - & - & - & $2(50)-$ & - & - \\
\hline Total & 2 & 1 & 5 & 10 & 11 & 7 & 8 & 4 & 3 & 1 \\
\hline & & & & & & & & & & \\
\hline
\end{tabular}

DFSP-Dermatofibrosarcoma protuberans, KA - Keratoacanthoma, PIH - Post inflammatory hyperpigmentation,

DF -Dermatofibroma, SK - Seborrheic keratosis, BCC- Basal cell carcinoma, LPP- Lichen planus pigmentosus, LCH- Lobular capillary hemangioma, CAVH- Cavernous hemangioma, AK - Angiokeratoma 
Out of 75 cases, 55(73.3\%) cases were consistent with both clinical and histopathological diagnosis, while $20(26.6 \%)$ cases were inconsistent (Table-5).

Table-5: Clinical and histopathological correlation of pigmented skin lesions

\begin{tabular}{|c|c|c|}
\hline Lesions & $\begin{array}{l}\text { Consistent with } \\
\text { clinical diagnosis }\end{array}$ & $\begin{array}{l}\text { Inconsistent with } \\
\text { clinical diagnosis }\end{array}$ \\
\hline Benign melanocytic nevi $(\mathrm{n}=13)(\%)$ & $11(84.6 \%)$ & $2(15.4 \%)$ Seborrheic keratosis \\
\hline Malignant melanoma $(\mathrm{n}=10)(\%)$ & $7(70 \%)$ & $\begin{array}{l}\text { 1(10\%) Basal cell carcinoma } \\
2(20 \%) \text { Nevus }\end{array}$ \\
\hline Dermatofibrosarcoma protruberans $(n=2)(\%)$ & - & $\begin{array}{l}\text { 1(50\%) Neurofibroma } \\
1(50 \%) \text { Fibroma }\end{array}$ \\
\hline Keratoacanthoma $(\mathrm{n}=1)(\%)$ & - & $1(100 \%)$ Squamous cell carcinoma \\
\hline Post inflammatory hyperpigmentation $(n=5)(\%)$ & $5(100 \%)$ & - \\
\hline Dermatofibroma (n=10) (\%) & $5(50 \%)$ & 2(20\%) Dermatofibrosarcoma protuberans, 3(30\%) Nevi \\
\hline Seborrheic keratosis $(\mathrm{n}=11)(\%)$ & $9(81.8 \%)$ & 2(18.2)) Nevi \\
\hline Basal cell carcinoma $(n=7)(\%)$ & $5(71.4 \%)$ & $2(28.6 \%) \mathrm{Nevi}$ \\
\hline Lichen planus pigmentosus $(\mathrm{n}=8)(\%)$ & $6(75 \%)$ & 1(12.5\%) Pityriasis rosea, 1(12.5)) Ashy dermatosis) \\
\hline Lobular capillary hemangioma $(n=4)(\%)$ & $4(100 \%)$ & - \\
\hline Capillary hemangioma $(n=3)(\%)$ & $3(100 \%)$ & - \\
\hline Angiokeratoma $(\mathrm{n}=1)(\%)$ & - & 1(100\%) Hemangioma \\
\hline
\end{tabular}

\section{DISCUSSION}

In our study, the pigmented skin lesions constituted $6 \%$ of all skin biopsies received over three years. Majority of them were non-melanocytic pigmented lesions 52(69.4\%) as compared to melanocytic lesions which were 23(30.6\%) (Table-1). Similar findings were reported in study by Prasad et al., [6]. However, in studies by Leishram et al., [5], Bohra et al., [7] and Parvathi et al [8] the incidence of PSLs of melanocytic origin was more. In our study, there was an increased presentation of PMLs in females 44 cases $(58.7 \%)$ as compared to males $31(41.3 \%)$ with male to female ratio of $1: 1.4$ (Table-2). Overall, benign melanocytic nevi were the most common lesion $13(17.3 \%)$ which showed increased preponderance among females $7(9.3 \%)$, similar to observations of Leishram et al., [5], Bohra et al., [7], Parvathi et al., [8] and Schafer et al., [9]. Most PSLs presented below 50 years of age. The findings were similar to Leishram et al., [5], Parvathi et al [8], Mackie et al., [10] and dissimilar with Youl et al., [11]. Most commonly involved site was the head and neck region including the face 29(38.6\%) (Table 4a \& 4b) which was in concordance with Leishram et al., [5], Bohra et al., [7] and Parvathi et al., [8]. Malignant lesions constituted $17(22.6 \%)$ of the study which included $10(13.3 \%)$ cases of malignant melanoma and $7(9.3 \%)$ cases of basal cell carcinoma. Clinical and histological concordance was achieved in 55(73.3\%) cases which was comparable with Parvathi et al., [8].

Melanocytic nevi are benign neoplastic proliferation or hamartomas of melanocytes [12]. Melanocytic nevi are not clinically apparent at birth with most nevi appearing in adolescence and early adulthood. Melanocytic nevi are characterized by the presence of nevus cells, which, though being melanocytes, differ from them by at least being partially arranged in clusters or nests, with the propensity to be round rather than having dendritic cell shape and a tendency to retain pigment in their cytoplasm. They follow a rather predictable evolution which is believed to begin as junctional nevi, become compound nevi and then intradermal nevi [13]. Rarely there can be a dramatic event such as spontaneous regression, activation or malignant transformation [14]. They may be papillomatous, pedunculated or flat and are more common in the skin of head, neck and trunk [15]. Histologically they are characterized by small nests or bundles of melanocytes in upper dermis with tendency to cluster around pilosebaceous units [16]. The degree of pigmentation and cellularity may vary considerably with lower half of the lesion being less cellular and less pigmented and more spindled with fibrillary cytoplasm [17] with 'Wagner -Meissner' type structures representing expression of neural component of nevus.

In the present study among the melanocytic pigmented lesions, we noted maximum number of intradermal naevi followed by compound nevi and congenital melanocytic nevus that was similar to study by Prasad et al., [6] and Shoko et al., [13]. All intradermal nevi were seen in the $2^{\text {nd }}$ to $5^{\text {th }}$ decade of life. These were distributed over facial region including cheeks, chin, ala of nose, forehead and eyelid varying in size from $0.4-1.5 \mathrm{~cm}$ with flat to papillary lesions presenting with tan to light brown pigmentation. Microscopically small nests of nevus cells were present in upper dermis surrounding pilosebaceous units with focal pigmentation with lower half of the lesion being less cellular and less pigmented and more spindled (Fig-1).

Compound melanocytic nevi show high incidence in $2^{\text {nd }}$ decade [18], are $3-6 \mathrm{~mm}$ papules, slightly elevated with homogenous light to dark brown pigment and features of both junctional and intradermal nevi. This lesion was diagnosed in three cases, all in $3^{\text {rd }}$ decade of life with distribution over cheek, back and abdomen. The lesions were slightly elevated, 
papulonodular, light brown in color varying in size from $1.5-3.5 \mathrm{~cm}$. Histologically there were epidermal and dermal component of nevus cells showing maturation towards depth of the lesion (Fig-2). Two of these lesions were clinically diagnosed as seborrheic keratosis because of epidermal hyperplasia over the lesion.

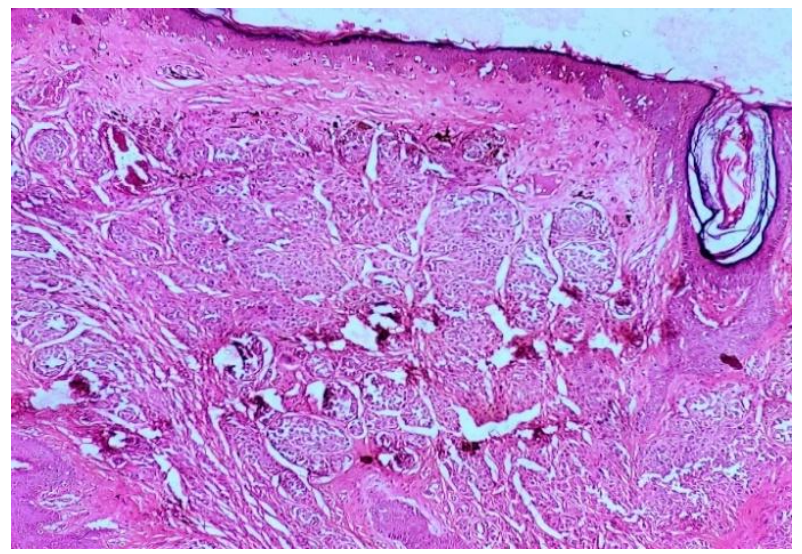

Fig-1: Intradermal nevus showing upper dermis containing nests and cords of nevus cells with variable pigmentation (H\&E)

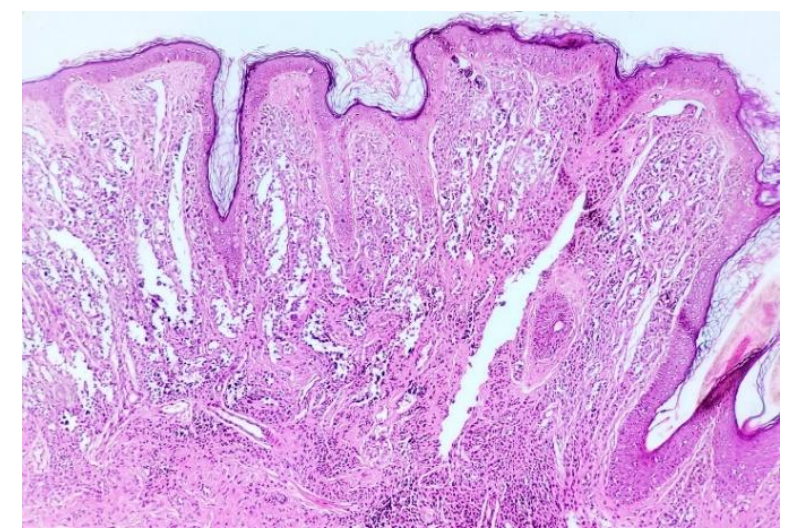

Fig-2: Compound nevus with junctional activity and nests and cords of nevus cells with variable pigmentation

$(\mathbf{H} \& \mathbf{E})$

Congenital melanocytic nevi are reported in about $1 \%$ of live births [19]. It is hypothesized that morphological error occurs in the neuroectoderm during embryogenesis, leading to unregulated growth of melanoblasts, which are the precursor cells of melanocytes [20]. A single case of congenital melanocytic nevus was reported in our study in a 65 years old male as a dark brown irregular macule over left side of forehead and eyebrow measuring approximately $5 \mathrm{~cm} \times 6 \mathrm{~cm}$ in size. It was present since birth. Microscopically, it was characterized by melanocytes clustered around follicles, adnexa, nerves and between collagen fibers at base of lesion.

In our study, we reported ten cases of malignant melanoma. All cases presented in late adulthood from $4^{\text {th }}-9^{\text {th }}$ decade of life and were distributed in both sun exposed and non-sun exposed areas including shoulder, neck, back, abdomen, labia and sole of feet, the latter location particularly being more common in women [21]. Also, there was an overall female predilection similar to observations by Parvathi et al., [8] and Leishram et al., [5]. All lesions varied in size from $2-3.5 \mathrm{~cm}$ with brown black pigmentation and irregular notched borders, unlike smooth round and uniform borders of benign melanocytic nevi (Fig-3). Melanoma is notorious for its great microscopic variability [22]. Histologically all lesions exhibited junctional activity, prominent melanin pigment, marked cytological atypia, large eosinophilic nucleoli, numerous mitotic figures and invasion of surrounding tissue (Fig-3).

Seborrheic keratosis is a benign keratinocytic pigmented skin lesion. It develops from the proliferation of keratinocytes of the epidermis [6]. Its common locations are the face, scalp, trunk, abdomen, back, and upper extremities. Unusual sites are conjunctiva, nipple, and areola [9]. In our study, among the non-melanocytic pigmented lesions, seborrheic keratosis was the commonest with 11 reported cases. Females were most commonly affected. Similar observations were reported by Leishram et al., [5] and Prasad et al., [6]. The most common age group affected was between the $3^{\text {rd }}-8^{\text {th }}$ decade. The lesions were brown black in color measuring $0.5-2.6 \mathrm{~cm}$ in size and distributed over scalp, face, shoulder, abdomen and lower limb. Microscopically, the lesions exhibited hyperplastic stratified squamous epithelium with multiple horn cysts and melanin pigment (Fig-4). Of the 11 cases, 02 cases were clinically not consistent as they mimicked nevi due to presenting as brownish black lesion occurring on sun exposed parts. In our study, the most common age group reported was in the $6^{\text {th }}$ decade, similar to Parvati et al., [8].

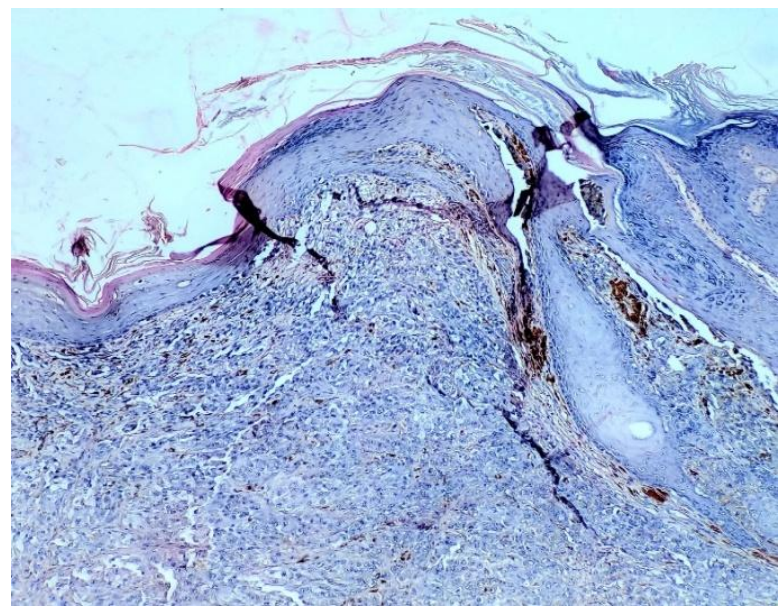

Fig-3: Malignant melanoma with junctional activity, melanin pigment and dermal involvement by atypical melanocytes without maturation (H\&E) 


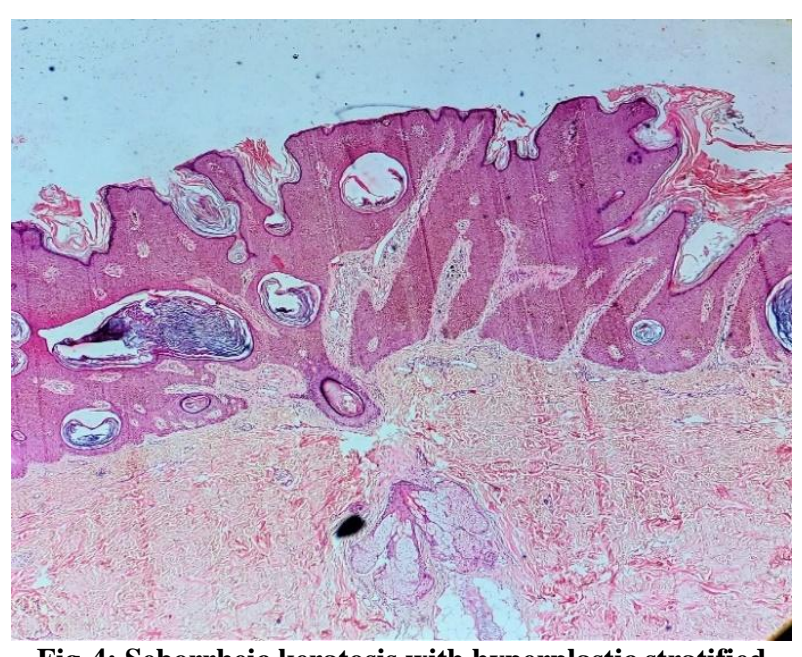

Fig-4: Seborrheic keratosis with hyperplastic stratified squamous epithelium with multiple horn cysts (H\&E)

Basal cell carcinoma is most frequent form of skin cancer primarily occurring on sun exposed skin due to UV exposure. It has been observed that they may also occur uncommonly on sun protected areas like legs in association with venous stasis, trauma, immunosuppression, arteriovenous malformations and $\mathrm{X}$-ray exposure [15]. In our study we reported 7 cases of basal cell carcinoma out of which 5 were distributed over face and 2 cases presented over thigh. All cases, in our study affected individuals between $6^{\text {th }}-9^{\text {th }}$ decade with female preponderance. The lesions presented as brown black nodules or papules measuring $1-2.5 \mathrm{~cm}$ in size. Two cases out of five were clinically misdiagnosed as nevi due to more regular uniform nodular pigmented lesion. Microscopically, proliferating nests of basaloid cells arising from epidermis and extending into superficial dermis were noted with cells showing prominent palisading surrounded by lose myxoid stroma. Focal cleft like spaces around nests of cells were also observed. There were scattered dermal malanophages with intracytoplasmic melanin between tumor nests (Fig-5). Basal cell carcinoma were also reported in studies by Leishram et al., [5], Prasad et al., [6] and Parvathi et al., [8].

We reported 02 cases of dermatofibrosarcoma protuberans (DFSP). Though trunk and extremities are the most common locations [23], the lesions in our study presented on the neck and scalp. Keeping in consistency that they occur commonly in early to midadulthood [23], the tumors in our study presented in $3^{\text {rd }}$ and $4^{\text {th }}$ decade as purple red raised lesions measuring 1.4 and $3.5 \mathrm{~cm}$ each. Microscopically, proliferation of spindle-shaped cells were seen in the deep dermis with focal infiltration in the subcutaneous fat with sparing of the epidermis. The spindled tumor cells were uniform in appearance with elongated nuclei and little or no pleomorphism and were arranged in a storiform manner. Scattered melanophages were noted (Fig-6). Cases of DFSP were also reported by Cresta et al., [24].

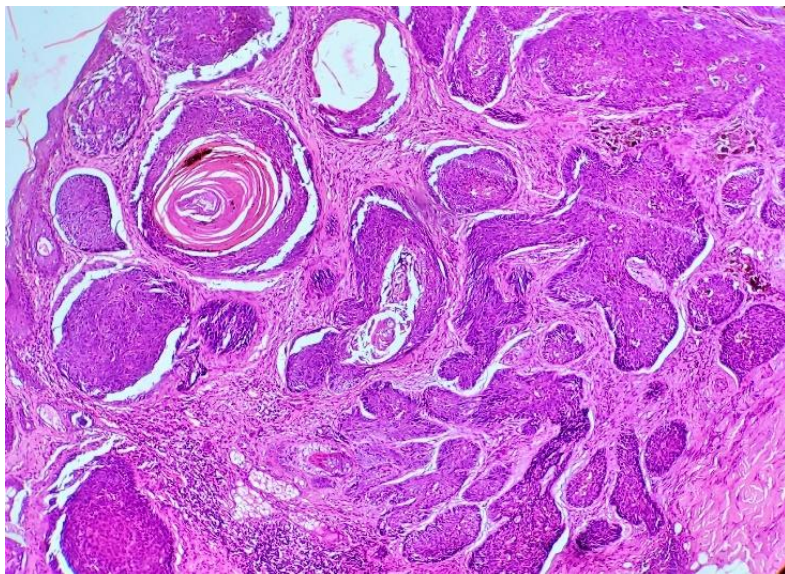

Fig-5: Basal cell carcinoma with nests of basaloid cells with peripheral palisading and dermal melanophages

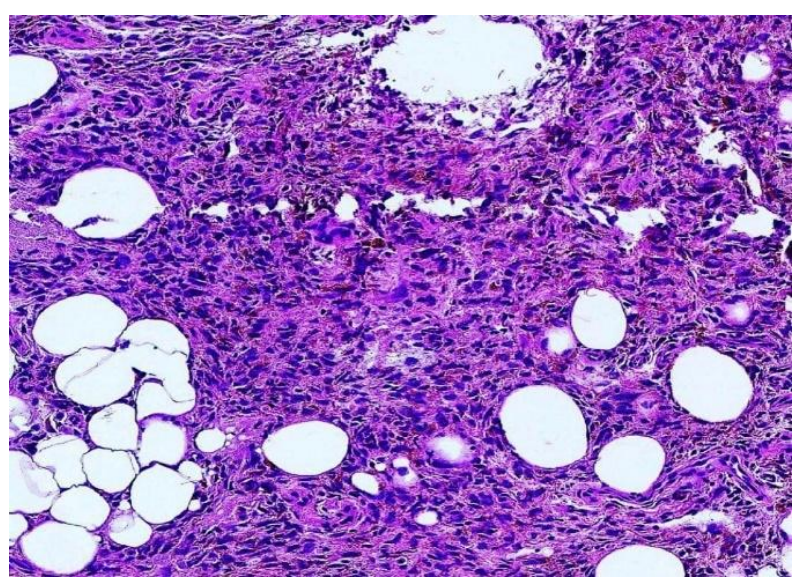

Fig-6: Dermatofibrosarcoma protuberans with spindle cells infiltrating Subcutaneous fat and scattered melanophages

Dermatofibromas account for almost $3 \%$ of dermatopathology and have a distinct predilection for the extremities, particularly the lower limbs, of young adults with females affected more than the males [25]. In our study, we reported 10 cases of dermatofibroma with females being affected more than males and majority presenting in the $4^{\text {th }}$ decade. The upper limbs were involved commonly followed by lower limbs and unusual presentation of one case on the upper lip. The lesions were polypoidal to flat plaques measuring $0.5 \mathrm{~cm}-1.5 \mathrm{~cm}$ with a dusky brown color. Microscopically, these were poorly circumscribed tumors mainly located in the dermis with extension into the superficial subcutaneous tissue and composed of a variable admixture of fibroblast-like cells, histiocytes and blood vessels (Fig-7).

We reported 8 cases of lichen planus pigmentosus (LPP). Contrary to the literature that LPP involve sun exposed areas of skin and occur in children and young adults [26], in our study the lesions presented between $4^{\text {th }}-5^{\text {th }}$ decade with no gender predilection and involved back, upper limbs, shoulder and penis. They presented as annular dark brown to violaceous plaques with slightly raised hypopigmented 
borders. Histologically, there was hyperkeratosis, atrophic epidermis with vacuolar alteration of the basal layer and scarce lymphohistiocytic to lichenoid infiltrates in the dermis with pigment incontinence (Fig8). Cases of LPP were also reported by Leishram et al., [5], Parvathi et al., [8] and Mruthyunjayappa et al., [27].

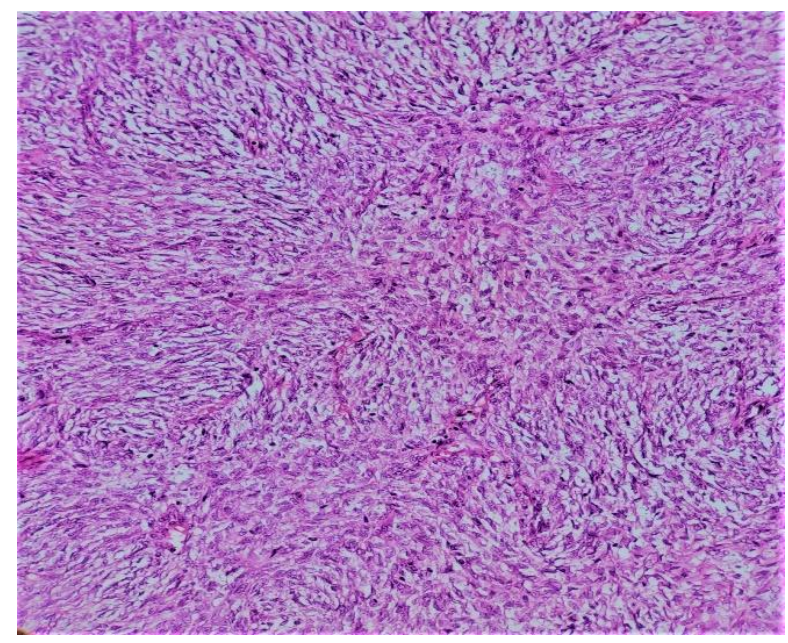

Fig-7: Dermatofibroma with proliferating fibroblasts, histiocytes with melanophages and blood vessels (H\&E)

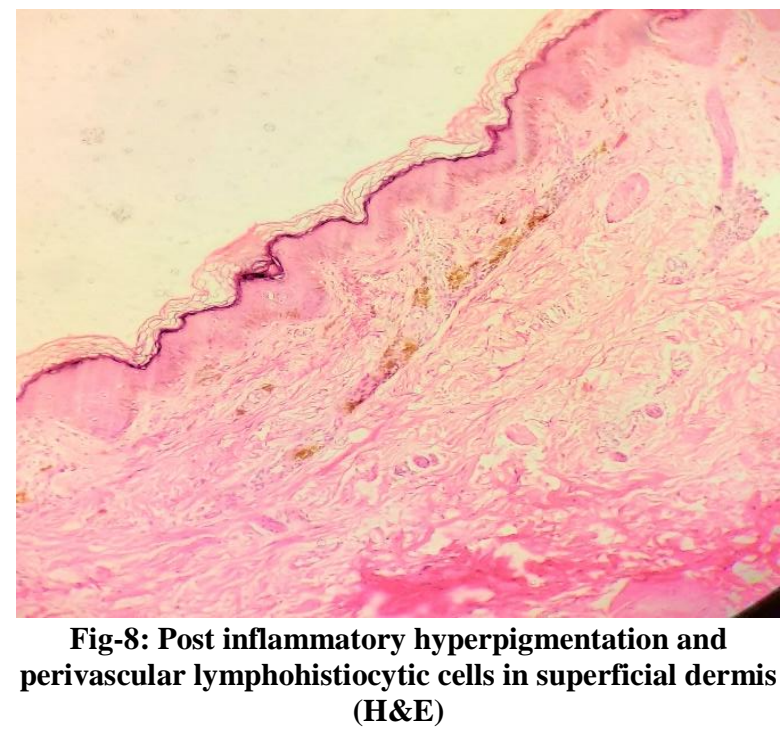

Another inflammatory pigmentary lesion reported was post inflammatory hyperpigmentation (PIH). It is an acquired hypermelanosis that occurs after cutaneous inflammatory conditions that more frequently affects skin-of-color patients [28]. We had 05 cases of $\mathrm{PIH}$, presenting between $2^{\text {nd }}-7^{\text {th }}$ decade and distributed over neck, thigh, gluteal region and abdomen as tan brown macules and papules with a male preponderance. Histologically, melanophages were present in the superficial dermis, along with a variably dense infiltrate of lymphohistiocytes around superficial blood vessels and in dermal papillae (Fig-8).
We reported a single case of keratoacanthoma in a 57year old male presenting as a flesh colored raised papule over scrotal skin. Originating in the pilosebaceous unit, keratoacanthomas are derived from an abnormality leading to hyperkeratosis of the infundibulum. They are associated with hair-bearing areas [29] Considered by some to be a highly differentiated form of squamous cell carcinoma, histological examination revealed a circumscribed proliferation of well-differentiated keratinocytes with the epidermis extending over the tumor, with a central horn plug of keratin and lip-like, peripheral borders of the epidermis. Intraepidermal neutrophilic abscesses were visualized in addition to horn pearls.

Vascular lesions can also present as pigmented lesions due to presence of underlying blood. They may appear black with the naked eye, but under dermatoscopy appear red, purple or blue [1]. In our study, $10.6 \%$ cases were of vascular etiology. All lesions were present in females with variable age distribution. There was 01 case of angiokeratoma which presented as a 1-6 mm red-blue, hyperkeratotic papule characterized by hyperplasia and hyperkeratosis of the epidermis along with multiple dilated vessels in the superficial dermis. There were 04 cases of lobular capillary hemangioma which showed distribution over scalp, hand and foot as globular reddish blue pedunculated masses, microscopically characterized as lobular proliferation of small blood vessels surrounded by a mixed cell population of fibroblasts, mast cells, lymphocytes and plasma cells. Feeding blood vessel was identified at the base of lesions. The 03 cases of cavernous hemangioma were distributed over chest and leg microscopically characterised by dilated, thin walled capillaries with a simple endothelial lining and fibrous adventitia. Angiokeratoma and hemangioma were also described by Bohra et al., [7] in their study.

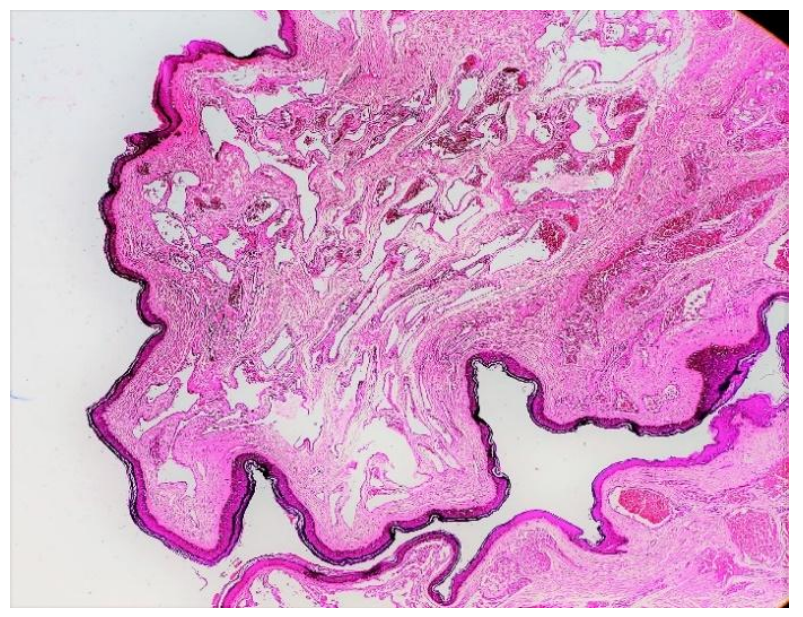

Fig-9: Cavernous hemangioma with dilated, thin walled capillaries and simple endothelial lining (H\&E) 


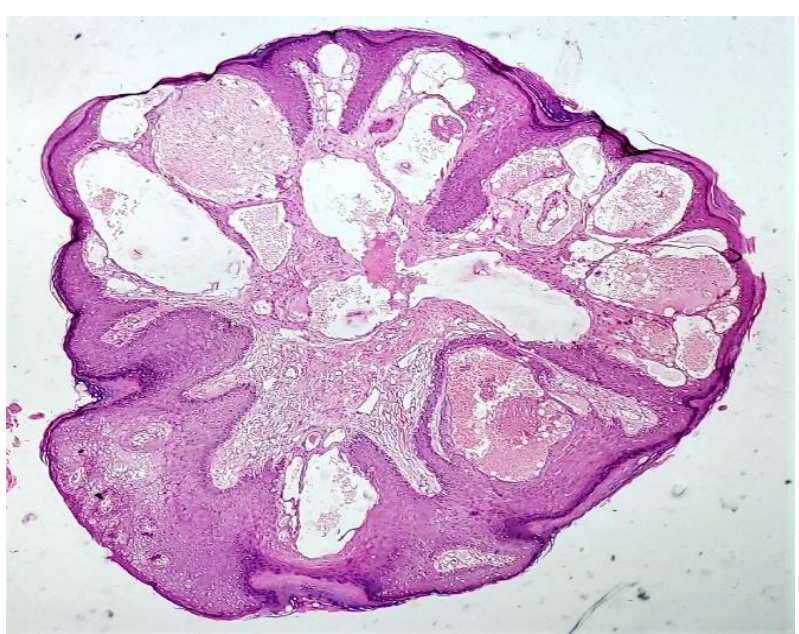

Fig-10: Angiokeratoma with hyperplasia and hyperkeratosis of the epidermis along with multiple dilated vessels in the superficial dermis

\section{CONCLUSION}

Both melanocytic and non-melanocytic lesions can present as PSLs among any age group. Histopathological confirmation is imperative whenever a pigmented lesion clinically mimicking melanoma is encountered as many of these may turn out to be nonmelanocytic and other benign melanocytic lesions on biopsy giving reassurance to the patient. A complete clinical diagnosis assists the histopathologist to give an accurate report.

\section{REFERENCES}

1. Pigmented skin lesions. (2015). In DermNet NZ. Retrieved 15 October 2020, from https://dermnetnz.org/topics/pigmented-skinlesions

2. Edwards, S. L., \& Blessing, K. (2000). Problematic pigmented lesions: Approach to diagnosis. J Clin Pathol, 53, 409-418.

3. Priyadarshini, D., \& Jeyachandran, P. (2014). Histopathological and Clinical Correlation of Hyperpigmented Skin Lesions. IJSR, 3(3), 10-12.

4. Elder, D. E., Elenitsas, R., Rosenbach, M., Murphy, G. E., Rubin, A. I., \& Xiaowei, X. (2015). Benign pigmented lesions and malignant melanoma. In Lever's Histopathology of the Skin. Elder, D. E., Elenitsas, R., Rosenbach, M., Murphy, G. E., Rubin, A. I. (Eds), Pp 1665-1854, Philadelphia, USA: Lippincott Williams and Willkins.

5. Laishram, R., Myrthong, B., Leishram, S., Shimray, R., Kumar, A., \& Sharma, D. C. (2013). Pigmented skin lesions: Are they all of melanocytic origin? A histopathological prospective. J Pakistan Assoc Dermatologists, 23(3), 284-88

6. Prasad, R. J., Suryakala, C., Arfathunnisa, M., Dasari, N., Killana, S. R., Karri, S., Indana, V. B., \& Atla, B. (2020). Clinicopathological study of pigmented skin lesions. $J$ Evid Based Med Healthc, 7(7), 337-341.
7. Bohra, I., Paudyal, P., Pradhan, A., \& Khadka, D. K. (2019) Pigmented skin lesions Clinicohistopathological Correlation: A hospital based study at BPKIHS. J Pathol Nep, 9, 1950-4.

8. Parvathi, M., Chowdari B., G. Divya Lekha., Kumar, S., \& Bhagya Lakshmi, S. A. (2017). Int J Res Med Sc, 5(12), 5316-5321.

9. Schäfer, T., Merkl, J., Klemm, E., Wichmann, H. E., \& Ring, J. (2006). The epidemiology of nevi and signs of skin aging in the adult general population: results of the KORA-survey 2000. J Investigative Dermatol, 126(7):1490-6.

10. MacKie, R. M., English, J., Aitchison, T. C., Fitzsimons, C. P., \& Wilson, P. (1985). The number and distribution of benign pigmented moles (melanocytic naevi) in a healthy British population. Brit J Dermatol, 113(2), 167-74.

11. Youl, P. H., Janda, M., Aitken, J. F., Del Mar, C. B., Whiteman, D. C., \& Baade, P. D. (2011) Body- site distribution of skin cancer, premalignant and common benign pigmented lesions excised in general practice. Brit J Dermatol, 2011, 165(1), 35-43.

12. Damsky, W. E., \& Bosenberg, M. (2019). Melanocytic nevi and melanoma: unraveling a complex relationship. Oncogene, 36(42), 57715792.

13. Shoko, M. (2002). The histopathological analysis of 531 cases of melanocytic nevus of the face. Jap J Dermatol, 112: 803-10.

14. Smoller, B. R., MCNutt, N. S., \& Hsu, A. (1989). HMB-45 recognizes stimulated melanocytes. J Cutan Pathol. 16(2), 49-53.

15. Billings, D. S. (2018). Tumors and tumor like conditions of the skin. In Rosai and Ackerman's Surgical Pathology. Goldblum, J. R., Lamps, L. W., Mc Kenney, J. K., \& Myers, J. L (Eds), Pp 4545-101, Philadelphia, USA: Elsevier

16. Sowa, J., Kobayashi, H., Ishii, M., \& Kimura, T. (2008). Histopathological findings in Unna's nevus suggest it as a tardive congenital nevus. Am J Dermatopathol, 30(6),561-566

17. Masson, P. (2002). My conception of cellular nevi. Cancer. 4(1):9-38

18. Winkelmann, R. K., \& Rocha, G. (1962). The dermal nevus and statistics. An evaluation of 1,200 pigmented lesions. Arch Dermatol, 86(9): 310-5.

19. Walton, R. G., Jacobs, A. H., \& Cox, A. J. (1976). Pigmented lesions in newborn infants. $\mathrm{Br} J$ Dermatol, 95, 389-396.

20. Takayama, H., Nagashima, Y., Hara, M., Takagi, H., Mori, M., \& Merlino, G. (2001) Immunohistochemical detection of the c-met proto-oncogene product in the congenital melanocytic nevus of an infant with neurocutaneous melanosis. J Am Acad Dermatol, 44,538-540.

21. Miller, J., \& Mihm, M. C. (2006). Melanoma. N Engl. J Med. 2006,355(1),51-65 
22. Banerjee, S. S., \& Harris, M. (2000). Morphological and immunophenotype variations in malignant melanoma. Histopathology. 2000,36(5):387-402

23. Dermatofibrosarcoma protuberans (DFSP). In Pathology Outlines.com. Retrieved 15 October 2020,

http://www.pathologyoutlines.com/topic/skintumo rnonmelanocyticdfsp.html.

24. Crasta, J., \& Rameshkumar, K. (2002). Pigmented lesions of non melanocytic origon: A pathological perspective. Indian J Dermatol, 47(2):84-87.

25. Niemi, K. M. (1970). The benign fibrohistiocytic tumours of the skin [Review]. Acta Derm Venereol (Stockh), 50,1-66
26. Bouassida, S., Boudaya, S., \& Turki, H. (1998). Actinic lichen planus: 32 cases. Am J Dermatol Venereol, 125,408.

27. Mruthyunjayappa, S., Mahantappa, H., Gopal, M. G., \& Venugopal, S. B. (2016). A study of spectrum of histopathological features in patients presenting with hyperpigmented skin lesions. Arch Med Health Sci, 4,189-95.

28. Chang, M. W. (2009). Disorders of hyperpigmentation. In Dermatology, Bolognia, J. L., Jorizzo, J. L., \& Rapini, R. P. (Eds). Pp 333389. Philadelphia USA, Elsevier.

29. Gibbons, M., Ernst, A., Patel, A., Armbrecht, E., \& Behshad, R. (2019). Keratoacanthomas: A review of excised specimens. $J$ Am Acad Dermatol, 80(6), 1794-1796. 